\title{
Galen and the Language of Old Comedy: Glimpses of a Lost Treatise at Ind. $23 \mathrm{~b}-28$
}

\author{
Amy Coker
}

Towards the middle of the $\pi \varepsilon p i$ ¿ $\lambda v \pi i$ ias, Galen singles out as a particular loss in the fire of AD 192 a treatise he had produced on the vocabulary of Old Comedy (Ind. 20-28). Galen describes this work in some detail at 23b-28, as follows:1

But Fate ambushed me, by destroying, along with many other of my books, most especially my work on the vocabulary of the entire of Old

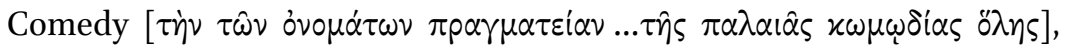
(24a) of which, as you know, Didymus had already made a study, both the everyday words and those requiring explanation $[\tau \dot{\alpha} \pi 0 \lambda \iota \tau \iota x \dot{\alpha} . . . \tau \dot{\alpha}$ $\tau \varepsilon \gamma \lambda \omega \tau \tau \eta \mu \alpha \tau i x \dot{\alpha} \pi \alpha \dot{\alpha} \tau \alpha]$, in fifty books, of which I made an epitome in 6,000 lines. (24b) Such a procedure seemed to be of some value for orators and grammarians, or in general for anyone who might want to use an Attic idiom [ significant bearing on practicalities, like the question that arose recently in Rome when a respected doctor announced that groats were not yet in

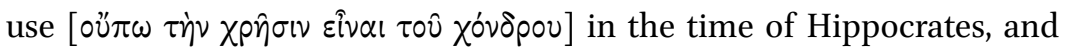
that that was why in Regimen in Acute Diseases he advocated barley gruel $\left[\pi \tau \sigma^{\sigma \alpha} \nu \eta \nu\right]$ over all other cereal foodstuffs; for if groats had been known to the Greeks, he would not have chosen anything else in preference. (26) But groats are mentioned particularly in Regimen for Health, which some ascribe to him but others to Philistion or Ariston, both very early doctors [ $\dot{\alpha} \nu \delta \rho \omega \nu \tau \alpha \lambda \alpha 10 \tau \dot{\alpha} \tau \omega \nu]$, and also in the writers of Old Comedy [ $\dot{\alpha} \lambda \dot{\alpha}$

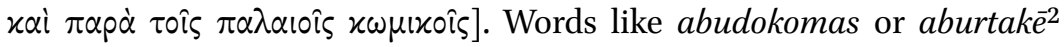

1 Trans. Nutton in Singer, Galen. Psychological Writings, 2013, pp. 85-6; the Greek text follows Boudon-Millot et al., Galien. Ne pas se chagriner $(2010)(=B J P)$, with the exception of the emendation at the end of 26 by Polemis, see n. 2 .

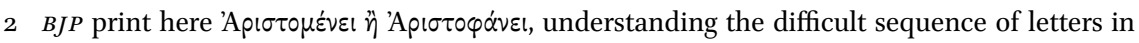
the manuscript as concealing the names of comic poets; Polemis (2011) $3^{-4}$ instead con-

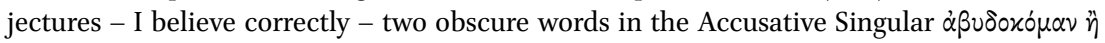
$\dot{\alpha} \beta u p \tau \dot{\alpha} x \eta \nu$, and is followed by Nutton (2013). The significance of these two words is discussed below. Polemis (2011) 4 also suggests a change in punctuation in the passage, and that the

(C) AMY COKER, 2019 | DOI:10.1163/9789004383302_005

This is an open access chapter distributed under the terms of the prevailing CC-BY-NC-ND License at the time of publication. 
$<$ and $>(27)$ whatever else was unclear to the audience were defined in our treatise - and was anticipated nicely in Didymus' exposition - as follows: emmer, chick peas, vetch, groats and the other cereals, vegetables and late-summer fruits, wines made from the marc of grapes, with or without the addition of water, bushes, fruits, plants, animals, instruments, equipment, tools, and everything else in daily life, and their names. (28) My

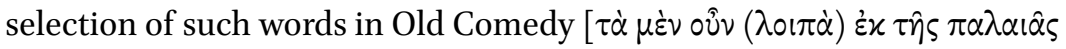

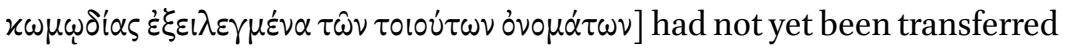
to Campania, but luckily my selection from prose authors already had, in forty-eight large books, of which those with the equivalent of more than 4,00o hexameter lines will perhaps have to be divided in two.

It is clear from the detailed exposition in this passage, and comments elsewhere in the Galenic corpus, that the language of Old Comedy was important for Galen, valuable as both a model of clarity of expression, and because of its practical utility in solving questions about the text of Hippocrates. None of Galen's works on Old Comedy have however survived. Rather than focussing on how Galen frames these losses listed here within the broader rhetorical strategy of the Peri alupias, ${ }^{3}$ this chapter takes this passage as a starting point for discussion of what Galen's monumental treatise on the vocabulary of Old Comedy lost in the fire would have looked like, using clues from both the Peri alupias, and mentions of comedy scattered throughout the rest of the Galenic corpus. In doing so, this chapter raises questions about the place of Galen within the wider literary culture of second-century AD Rome, rather than considering him solely as a physician or philosopher.

Firstly, after discussing in brief the place of Old Comedy within Galen's view of language, ${ }^{4}$ quotations from comic texts in the works of Galen extant in Greek are collected in order to allow an overview of his preferred authors, suggesting perhaps the range of authors included in the lost work. Secondly, a close reading of the final part Ind. $23 \mathrm{~b}-28$ allows further speculation about the source-texts and format of Galen's work on Old Comedy, as well as about

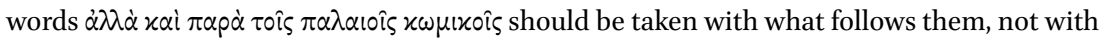
what proceeds. On this basis, with a full stop after 'doctors' in Nutton's version, an English translation might read 'But also from the playwrights of Old Comedy, the words Abudokomēs or aburtake, and/or $\langle\dot{\eta}\rangle$ others not clear to the audience were defined in our treatise - and was anticipated nicely in Didymus' exposition - as follows'. Sense-wise, it is difficult to chose between either version, although see the comments in n. ooo, this chapter.

3 On which see Rosen (2014).

4 A study of the use of the vocabulary of Old Comedy itself within Galen's Greek is beyond the scope of this chapter, and a desideratum of future work. 
his working practices more broadly. As will be shown, Galen's oeuvre has more in common with lexicographically-informed works of the second century AD, and Galen with their authors whom he pejoratively labels 'sophists', than his scathing remarks about their linguistic endeavours sometimes suggest. ${ }^{5}$

\section{Galen's Atticism \& Galen's Comedy}

Despite writing at a period of fervent interest in the revival of Attic Greek as the aspirational standard of the educated man, ${ }^{6}$ it is well known that Galen is critical of those who seek to reproduce apparent Attic norms for their own sake, especially if this is at the expense of clarity. ${ }^{7}$ For Galen, it is precision above all which should dictate matters of linguistic expression. Adherence to strict antiquarian norms are not useful per se, but some words from the sunètheia of the Classical past - if used correctly - can be tools for maintaining clarity: this is explicit in Galen's own words at the end of his treatise The Order of My Own Books: ${ }^{8}$

It was because of the number of doctors and philosophers who lay down new meanings for Greek words [...] for this reason I made this commentary on the words which I collected in forty-six books from the Attic prosewriters (and some others from the comic poets [ $\kappa \alpha \theta \dot{\alpha} \pi \varepsilon \rho \dot{\varepsilon} \kappa \tau \hat{\omega} \nu \varkappa \omega \mu \iota \kappa \hat{\omega} \nu$ $\alpha \lambda \lambda \alpha]){ }^{9}$ The work is, as I have explained, written for the sake of the actual objects signified; at the same time, the reader gains a knowledge of Attic

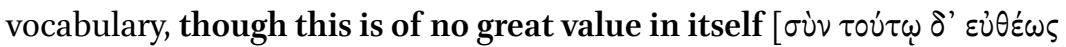

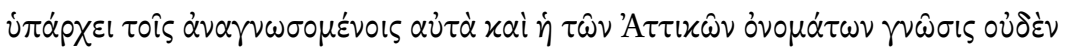

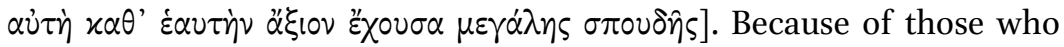

5 Nutton (2009) 34 highlights this as a distinct - albeit perhaps controversial - possibility, cf. Kollesch (1981). As Zadorojnyi (2013) 389 puts it, "Notwithstanding his dislike of 'sophistry', Galen is a dextrous (if grouchy) self-promoter well-versed in the challenges and strategems of the Second Sophistic."

6 See Kim (2010) for a recent state-of-the-art account of linguistic archaism in the first two centuries AD, which stresses the internal variety of Atticism; Swain (1996) and Schmitz (1997) are now classic works on the topic.

7 See for example von Staden (1995) 516 with further references, and Sluiter (1995); Hankinson (1994), esp. 171-180, dicusses Galen's principles of naming, as does Morison (2008); Barnes (1997) explores Galen's apparently "schizophrenic" attitude to language, ambivalence mixed with strictness.

8 Ord. Lib. Prop. 5.4-6 (= XIX.61 K.) ed. Boudon-Millot, trans. Singer (1997) 28-9.

9 The same work on prose mentioned at Ind. 28, and listed by Galen in Lib. Prop. 20.1 (see below n. 17), as being in 48 books. 
use words badly, however, I composed another work, on their correctness

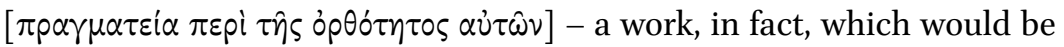
best read first of all.

Here it can be seen that it is the misuse of vocabulary with novel meanings which riles Galen - a concern he held in common with the Atticist lexicographers - and it is for this reason that he produced a work for the specific purpose of elucidating the proper meaning of words. ${ }^{10}$ These works are not catalogues of philological ornaments, as the efforts of those who hyperAtticise' were sometimes characterised by the more satirical commentators of the period. ${ }^{11}$ Such works are associated in particular with Phrynichus and his ilk, a kind of scholarly enterprise from which Galen seeks to distance himself, despite sharing much common ground.

The most overt indication that it is words from Attic Comedy, as opposed to those from other varieties of the Classical language, which for Galen are the most useful in maintaining his principle of clarity, is found in the first book of

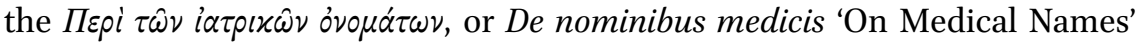
(Med. Nom.), a text which survives only in Arabic translation. ${ }^{12}$ Here Galen tells us it is Aristophanes' usage of words which should be followed as a model because of the intelligibility of the language of the comic theatre for the populace in general. ${ }^{13}$ This explains in part why in Galen's other catalogue of his works, On My Own Books, no fewer than five treatises on comedy and comic playwrights are listed (Lib. Prop. $20.1=$ XIX.48 K.). Going by their titles which, notwithstanding any new discoveries is all that survives of these works, there is one on the vocabulary of each of the 'big three' playwrights of Old Comedy (Cratinus, Aristophanes and Eupolis), ${ }^{14}$ and two more general works, one on

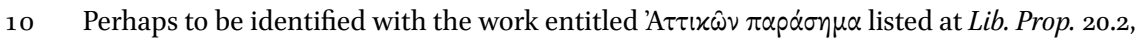
see n. 17 , but otherwise unknown.

11 See for example the figure of the teacher of rhetoric in Lucian's Praeceptor rhetorum, esp. 17; compare Galen's own comments at PHP 5.7.42.

12 Meyerhof \& Schacht (1931) gives the Arabic text and translation into German; a brief history of its transmission in Arabic and Syriac is given at (1931) 4; Deichgräber (1957) discusses the text and its significance for Galen's principles of naming. On comedy and clarity see von Staden (1995) 81-2.

13 Meyerhof \& Schacht (1931) 31-3 (= 103v-104v).

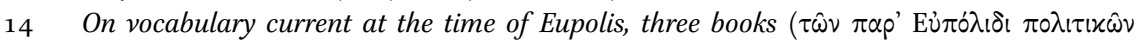

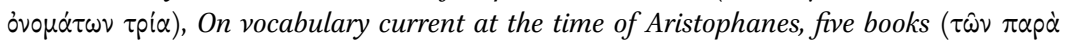

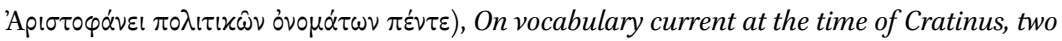

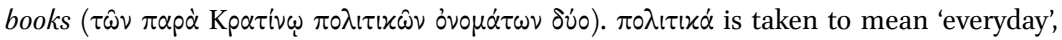
as for example Nutton (2009) $30 \mathrm{n}$. 76 and Rosen (2014) 168, against other translations as 
vocabulary found only in comic plays, ${ }^{15}$ and one on the utility of Old Comedy as reading for students. ${ }^{16} \mathrm{~A}$ number of other works on language are also listed

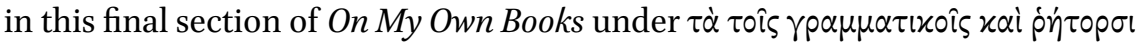
xovvd, ${ }^{17}$ but not the 6,ooo line epitome of Didymus on Old Comedy mentioned in the Peri alupias. ${ }^{18}$ Presumably after the destruction of this work in AD 192 Galen did not (or could not, through the loss of his source texts) reproduce it or, if he did, he reworked or rearranged the material so that it could be called by a different name, and it lurks behind one of the titles Galen lists in catalogues of his own works.

The loss of all of Galen's works on Old Comedy necessitates an alternative approach to the matter of which comic texts or comic playwrights he is using or reading. The list below stands as a first pass at capturing mentions of comedy and comic playwrights in Galen's extant works, assembled through electronically searching the online Thesaurus Linguae Graecae (TLG). ${ }^{19}$ This is an admittedly crude approach and does not claim to provide a comprehensive account of Comedy in Galen, yet produces a larger amount of material than hitherto collected, and allows some positive statements to be made about the

'political'. Sluiter (1995) 524 suggests an opposition in Galen of language which is normal or proper ( $\pi 0 \lambda$ เाixós), and that which is rhetorical.

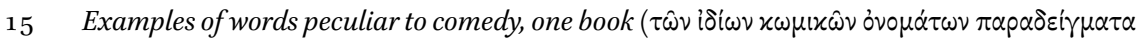
हैv).

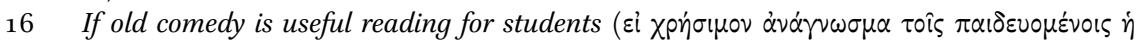
$\pi \alpha \lambda \alpha i \dot{\alpha} x \omega \mu \omega \delta i \alpha)$, perhaps reminiscent of Plutarch's earlier Comparison of Aristophanes and Menander (Mor. 853a-854d).

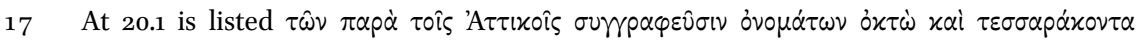

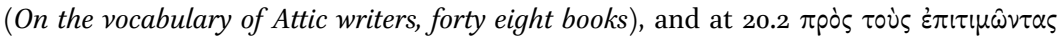

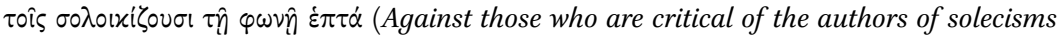

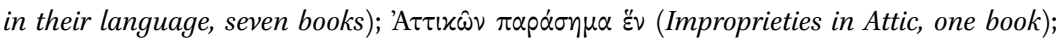

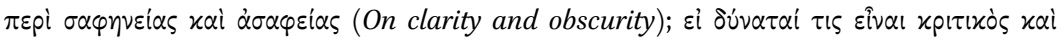

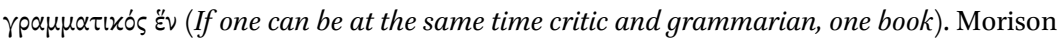
(2008) 116-7 gives a convenient list of Galen's works on language, Skoda (2001) a sketch of his lexicographical interests; she dubs Galen "un amateur de lexicologie et de linguistique" (p. 194).

18 At Ind. 28 Galen tells us that 4000 hexameter lines is around the upper limit for the length of a single book, suggesting perhaps that Galen's epitome was in two books. On ancient book lengths see $B J P$ ad loc (pp. 94-5), and especially Johnson (2004) 87-8, 143-6o, who stresses the complexity of identifying a standard length for a papyrus bookroll.

19 http://stephanus.tlg.uci.edu/. Searches took place in June 2014, and were checked again in May 2015. The initial search strings were $\chi \omega \mu l \chi, ~ \varkappa \omega \mu \omega \delta$ (to catch general references), $\dot{\alpha} \rho \sigma \tau 0 \varphi, x \rho \alpha \tau \imath \nu, \varepsilon \dot{\pi} \pi \partial \lambda, \mu \varepsilon v \alpha v \delta$ (for playwrights) and $\lambda v \sigma l \sigma \tau \rho, \theta \varepsilon \sigma \mu \circ \varphi, \beta \alpha \tau \rho \alpha \chi 0, \varepsilon \varkappa \varkappa \lambda \eta \sigma l$, $\pi \lambda \circ v \tau 0, \alpha \chi \alpha \rho \nu, i \pi \pi \varepsilon, \nu \varepsilon \varphi \varepsilon \lambda \alpha, \sigma \varphi \eta x, \varepsilon i p \eta \nu, ~ o p v i \theta$ (as a sample for finding plays, based around the eleven extant complete plays of Aristophanes). All texts listed in the TLG under "Galen" and "Ps-Galen" were searched, with "Ps-Galen" yielding no results. 
extent of Galen's knowledge of ancient comic texts. ${ }^{20}$ Quotations are listed first (1.1), with the quoted text in footnotes, followed by additional mentions of names of plays, playwrights, or 'a comic poet' divided into those which make linguistic comment (1.2) and those which are more general $(1.3) .^{21}$

\subsection{Quotations from Comic Plays in Galen}

Hipp. Art. XviIIa.340 K.

Aff. Dig. 7.10 (CMG V 4.1.1) (= V.38 K.)

Diff. Puls. VIII.653 K.

Dig. Puls. VIII.943 K.

SMT 11.37 (= XII. $360 \mathrm{~K}$. )

Gloss. XIX.113 K.

Gloss. XIX.66-7 K.
Eupolis, fr. 6o K-A

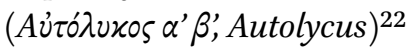

Eupolis, fr. * 105 K-A $(\Delta \hat{\eta} \mu \circ \text {, Demes })^{23}$

Eupolis, fr. * 116 K-A $(\Delta \hat{\eta} \mu \circ \iota, \text { Demes })^{24}$

Eupolis, fr. *116 K-A ( $\Delta \hat{\eta} \mu \mathrm{ol}$, Demes)

(= previous note)

Aristophanes, Birds 471

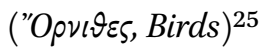

Aristophanes, Acharnians 872

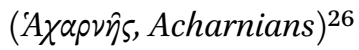

Aristophanes, fr. 205 K-A

$(\Delta \alpha \iota \tau \alpha \lambda \hat{\jmath} \varsigma \text {, Banqueters })^{27}$

20 Some quotes from Comedy in Galen are listed in Nutton (2009) 29-31, who also considers Galen's reading of classical literature more broadly; compare too the collection by von Staden (1998) 81-2, n. 56. As a check, all the citations given under Galen in the index to Rusten (2011) 740 are captured by this method: the true test will be when the volume of Indices to Poetae Comici Graeci appears. De Lacy (1966) is more limited than its title suggests.

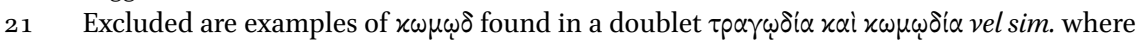
these refer to comic competition or performance, e.g. Comp. Med. Loc. XIII.6 K., UP IV. 356

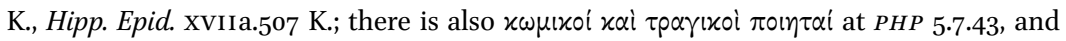
$H N H$ XV.24 K. (= comm. 1.2, on which see n. 58), cf. also von Staden (1998) 68 n. 12, 70 n. 25. Examples of the search words in Lib. Prop. and Ord. Lib. Prop. are also excluded.

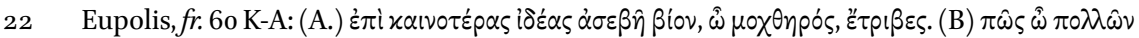

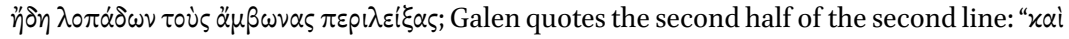

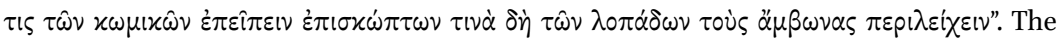
quotation in Galen is identified in Manetti (2009) 165.

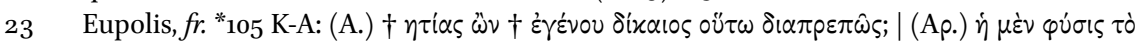

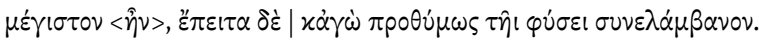

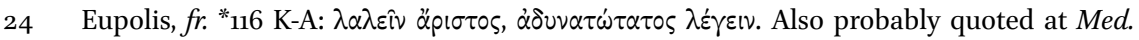
Nom. (Meyerhof-Schacht 1931, 31 = 102v).

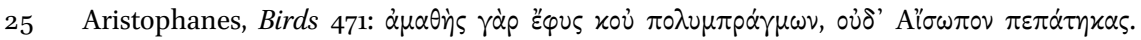
Kühn's text of Galen has $\mu \varepsilon \mu \dot{\alpha} \theta \eta x \alpha \varsigma$ as the final word.

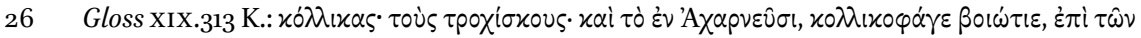

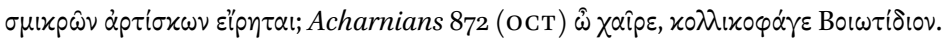

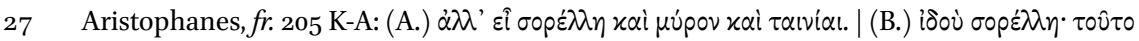

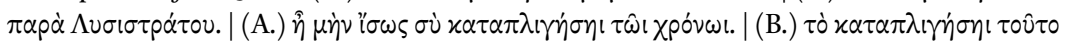


Gloss. XIX.65 K.

Alim. Fac. 1.27.1 (CMG V 4.2)

(=VI.541 K.)

Hipp. Aph. XVIIIa.148 K.

Hipp. Fract. XVIIIb.347 K.

Med. Nom (Reconstructed from

Arabic, see Deichgräber 1957)

Hipp. Aph. 7.149 (CMG V 4.1.2)

(= XVIIIa.149 K.)

Qual. Incorp. XIX.467 K.

PHP $4.6 .34(=$ V.412 K.)

Diff. Puls. VIII.656 K.

Hipp. Art. XVIIIa.531 K.

Di.Dec. IX.814-5 K.
Aristophanes, fr. 233 K-A

$(\Delta \alpha i \tau \alpha \lambda \hat{\eta} \varsigma, \text { Banqueters })^{28}$

Aristophanes, fr. $428 \mathrm{~K}-\mathrm{A}$

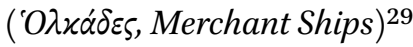

Aristophanes, fr. 526 K-A

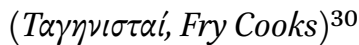

Aristophanes, fr. $630 \mathrm{~K}-\mathrm{A}$

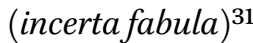

Aristophanes, fr. 346 K-A

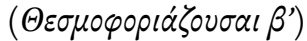

Plato (= Plato comicus) fr. 200 K-A

(incerta fabula $)^{32}$

Menander, fr. 477 K-A

(incerta fabula) ${ }^{33}$

Menander, fr. 476 K-A

(incerta fabula $)^{34}$

Adespota fr. 229 K-A 35

"Aristophanes", according to Galen ${ }^{36}$

'The Comic'37

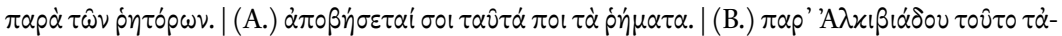

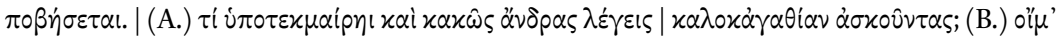

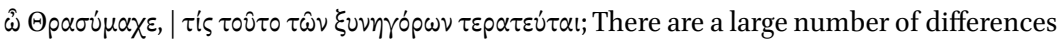
between Kühn's text of Galen and the fragment reconstructed in $P C G$.

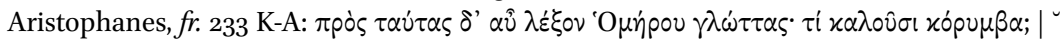

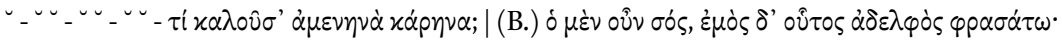

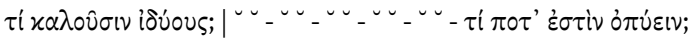

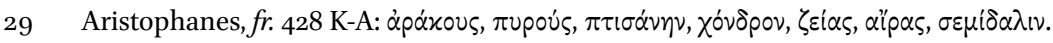

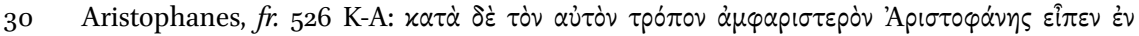

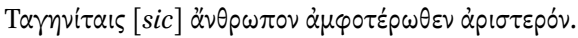

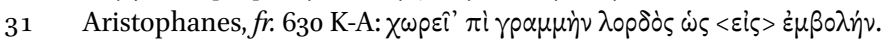

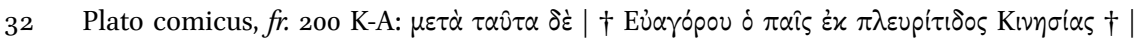

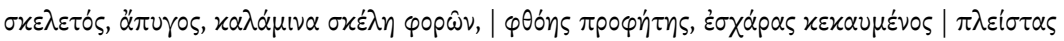

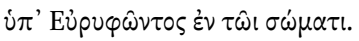

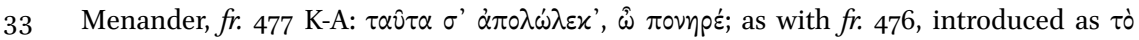

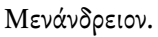

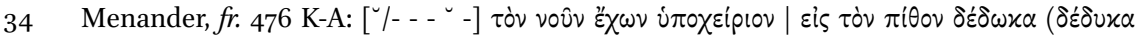
Cobet).

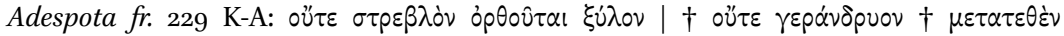
$\mu \circ \sigma \chi \varepsilon \dot{\varepsilon \tau \tau l .}$

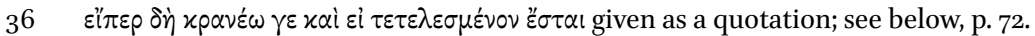

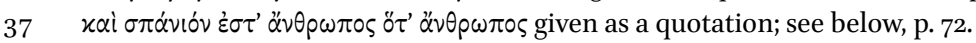


1.2 Additional 'Linguistic' Observations without Quotation

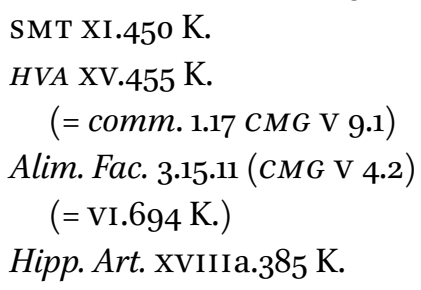

On spelling ( $\chi \cup \lambda o ́ s / \chi \cup \mu o ́ s)$

Comic poets using the word $\chi o ́ v \delta$ pos

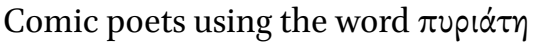

Explanation of $\tau \imath \mu \omega \rho \varepsilon \circ v^{\sigma} \sigma \varsigma$ using the title of a play by Menander

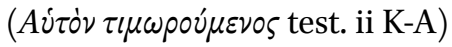

\subsection{Reports of Jokes and Other Observations without Quotation}

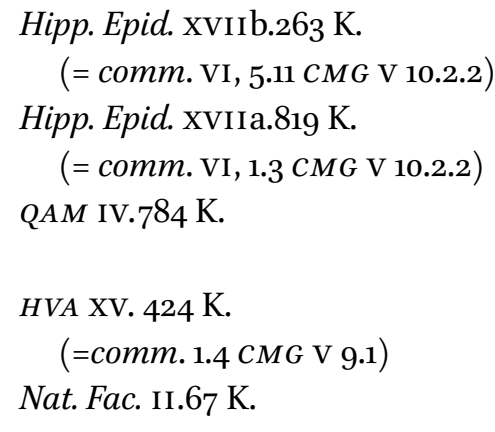

Mockery of Socrates in Aristophanes' Clouds

Comic poets joking about the size of Pericles' head

Hippocrates' sons as exemplars of foolishness

Example from Eupolis, $A \dot{v} \tau o ́ \lambda v \varkappa o s \beta$

(Eupolis, Autolycus test. ii K-A)

Menander as a writer of comedy

(Menander test. ${ }_{115} \mathrm{~K}-\mathrm{A}$ )

(passage below, pp. 74-5)

The most immediate feature of this collection is its paucity; even if one allows for citations which have not been captured by these electronic searches, such as those labelled with playwright names or play titles not searched for, relative to the size of the Galenic corpus this collection of examples is very small. Perhaps this indicates that Galen restricted his discussion of comedy relatively strictly to those treatises explicitly on comedy, or rather that Galen just does not give a reference for quotations when used: this may be the case with the as yet unidentified line from On Critical Days (Di. Dec. Ix.814-5 K., last item of [1.11]) which has at least the benefit of being tagged as "comic".38

As can be seen, comic material is used widely in the commentaries on Hippocrates, ${ }^{39}$ echoing Nutton's comments on Galen's use of Classical litera-

38 This suggests the tantalising possibility that there are other unidentified snippets of ancient literature still hidden in the Galenic corpus.

39 As well as several times in Diff. Puls., a work in which according to Hankinson (2008) 173, "irritations over language are a constant refrain"; metaphor is also discussed at length in this work, see von Staden (1995), esp. 500-13. On the commentaries in general, see 
ture in general to elucidate Hippocratic texts. ${ }^{40}$ Note too that in the Peri alupias passage, the problem given as an example of what Galen's work on Old Comedy could help solve is also Hippocratic in nature: were groats (Xóvôpos, whole grains) in use in Hippocrates (the answer being yes, so the 'respected doctor in Rome' is wrong). ${ }^{41}$

In the Hippocratic commentaries, and elsewhere, comic material is sometimes used to make points about language, but not always. As can be seen from the lists of citations which do not include quotations $(1.2,1.3)$, some do talk about language but many have rather an anecdotal quality, and refer to ancient jokes or sayings as opposed to commenting on any philological content. Likewise, many of the direct quotations are given by Galen for their encyclopedic or gnomic quality: we find for example Menander cited as part of a discussion on the loss of reason ( $P H P$ 4.6.34), Plato (the comic playwright) alongside the cautery of abscesses (Hipp. Aph. XVIII a.149 K), and Aristophanes' Birds

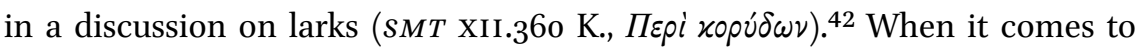
linguistic matters, we find texts quoted to illustrate matters of spelling (Alim. Fac. 1.27.1 on the spelling of the name of äpaxos, 'wild chickling'), vocabulary (words for left-handedness at Hipp. Aph. XVIIIa.148 K., the difference between $\lambda \alpha \lambda \varepsilon i \bar{\nu}$ and $\lambda \varepsilon^{\prime} \gamma \varepsilon i \nu$ at Diff. Puls. VIII.653 K.) and on the invention of new words (Gloss. XIX.65-7 K.); at Hipp. Art. XVIIIa.385 K., the title of a play by Menander is adduced to explain the meaning of a tricky participle in Hippocrates (on which more shortly).

As to the material from which Galen was drawing these examples, the statement in Med. Nom. that Aristophanes is the best model is corroborated by the predominance of quotations from, and references to, this playwright in the extant works. We could expect from the preservation of the titles of lost works by Galen on Cratinus, Aristophanes and Eupolis (see n. 14) that the first and last of these playwrights would also figure, and we do indeed find three quotations from Eupolis - but three only - and none from Cratinus. There is one quotation from Plato (comicus). Two of the Eupolis quotations are from $\Delta \hat{\eta} \mu$ o (Demes),

Manetti \& Roselli (1994), esp. 1571-1575, and Hanson (1998) passim on what they reveal about Galen's attitude to authorship.

$40 \quad$ Nutton (2009) 29.

41 In the edition of $B J P$, and Nutton's translation as reproduced here, Galen gives the use of

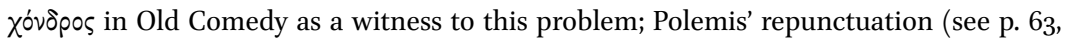
n. 2) on the contrary construes 'from Old Comedy' with the description of the treatise which follows. Either way, Galen mentions this word as used in comedy (again) at HVA XV. $455 \mathrm{~K}$.

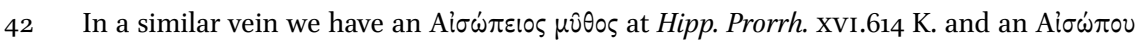
$\lambda$ óros at $A d v$. Jul. xvinia.291 K.; stories from Aesop also appear alongside the quotation from Aristophanes' Birds. 
and while one of these is attached to the name of Eupolis ( $f r$. *105 K-A), the

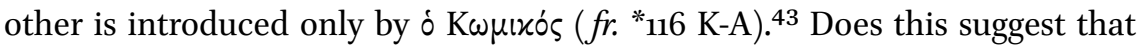
for Galen Eupolis had a kind of pre-eminence, the same way that Homer is often simply "The Poet"? If this is the case, does this in turn imply that the line quoted at Diff. Puls. viII.656 K. (= Adespota fr. 229 K-A) and introduced by "the Comic" should also be attributed to Eupolis? Even more speculatively, does it follow that there is an unseen quotation of Eupolis in the passage from $\mathrm{On}$ Critical Days (Di. Dec. Ix.814-5 K.)?:

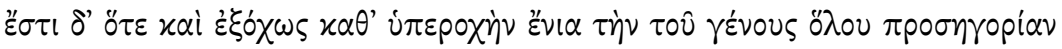

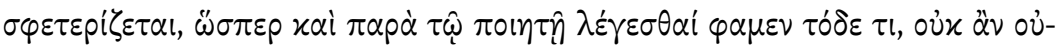

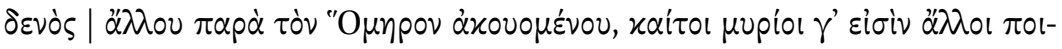

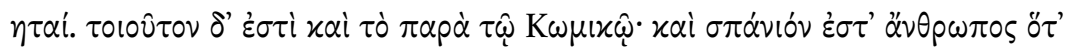

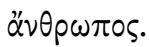

Sometimes a thing appropriates through its prominence the name of a whole class, just as when we say that something is said in the work of 'a poet', we understand only that it is in Homer and no-one else, even though there are countless other poets. This sort of thing is found in the Comic: 'a man who is just a man is a rare thing'.

If the final words of this passage are indeed a quotation, as printed in Kühn they are almost a trimeter, with one syllable missing. Alternatively - and more likely - is that "The Comic" in this passage of On Critical Days is in fact Aristophanes, which would seem more likely on the basis of the prestige given him elsewhere by Galen, meaning that fr. ${ }^{*} 116$ from $\Delta \hat{\eta} \mu$ ol (Demes) is misattributed by Galen, if we assume that he uses the label $\delta$ K $\omega \mu$ uxós with any consistency. Have we caught Galen making a mistake? So too, Galen quotes a line he attributes to Aristophanes at Hipp. Art. XviıIa. 530-1 K.:

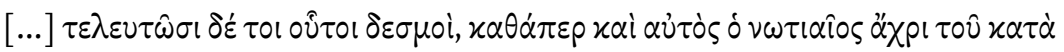

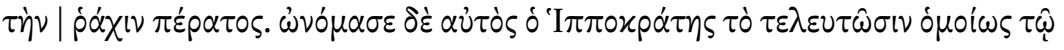



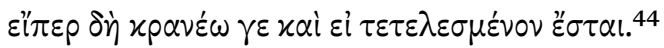

43 Capital as Kühn. Both Plutarch (Alcib. 13.2) and Aulus Gellius (1.15.12) attribute the words of this fragment $\left(f r\right.$. ${ }^{* 116)}$ to Eupolis.

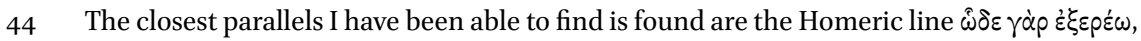

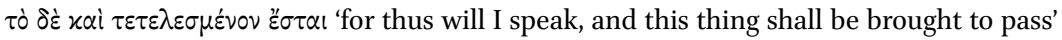
(found several times, with some initial variation e.g. Iliad 1.212, 8.401, 23.410, etc.) and a 
This line does not appear among the fragments of Aristophanes in PCG, but nonetheless Galen thought it was Aristophanic. If there is misattribution in Galen in either of these examples (especially Eupolis, fr. *116), is this Galen slipping up, or his source? Or, more simply, does the use of the tag $x \omega \mu$ uxós imply Galen does not know from which poet this quotation comes? (And did he ever know?) This raises the question of the nature of Galen's sources for these quotations, and whether he is reading plays in full, or drawing only from compilations or lexica, as his reference to Didymus in the Peri alupias suggests. ${ }^{45}$ There are similar examples of such misattribution in Latin texts of the late Republican and Imperial period which appear to indicate the use of anthologies, or similar sources, of ancient Greek comic plays, rather than engagement with complete texts. ${ }^{46}$ It should be noted that most of the quotations are not introduced by Galen with anything approaching a modern-style reference, and in some examples are not obviously quotations: play names are given rarely, ${ }^{47}$ and as we have seen poets are not always named in association with quoted words or lines. ${ }^{48}$ Similarly, sometimes we find simply phrases

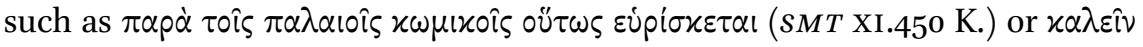

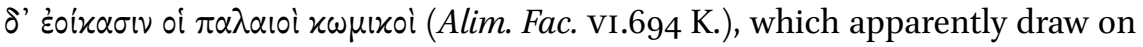
Galen's knowledge of Old Comedy, but yet are unsubstantiated by examples. Galen's characteristically confident statements about wide reading of Classical texts should be treated with some considerable caution. ${ }^{49}$ Before moving on to these questions of sources, a few words on Menander.

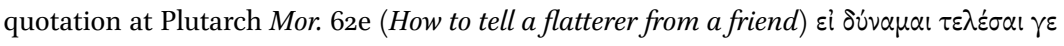

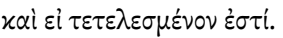

45 von Staden (1998) $68 \mathrm{n}$. 12 notes for example that some of Galen's quotations are probably at second hand.

46 See for example the misattributions collected by Ruffell (2014) 304 from Cicero, Valerius Maximus and Vitruvius; in Cicero (Att. 12.6a), a quotation from Eupolis mistakenly attributed to Aristophanes' Acharnians is corrected, see ibid p. 292, n. 64 on this example.

47 I found only Gloss. XIX.66 K. Banqueters (twice) and at 113 Acharnians; SMT XII.36o K. Birds; Hipp. Aph. XviıIa.148 K. Fry Cooks; Alim. Fac. vi.541 K. Merchant Ships; Hipp. Epid. XVIIb.263 K. Clouds; and HVA XV.424 K. Autolycus. None of these play names recur elsewhere in Galen.

48 The names of playwrights are associated with quotations for example at Aff. Dig. v.38 K. (Eupolis), Hipp. Fract. Xvinıb.347 K. (Aristophanes) and Hipp. Aph. XVIIIa.149 K. (Plato comicus). Excluding Galen's catalogues of his own works, Aristophanes is named eight times in the extant Greek works, Eupolis twice.

49 We find such confidence in the rhetoric of control over his material at for example Med. Nom. (Meyerhof-Schacht 1931, $33=$ 103r-104v): "Ich könnte dir nachweisen, daß alle Komödiendichter den Namen”Fieber" | in ihrer Redeweise ebenso anwenden, mit zahlreichen zum Beweise dienenden Belegstellen aus ihren Worten, mit denen man, 
So far the discussion has centred around Old Comedy, since this makes up the bulk of the material in Galen, and indeed it is a work on $\dot{\eta} \pi \alpha \lambda \alpha i \dot{\alpha} x \omega \mu \omega \delta \delta^{\prime} \alpha$ specifically which Galen talks about in the Peri alupias. ${ }^{50}$ However, there are a few references to Menander, a playwright of New Comedy. ${ }^{51}$ This is perhaps surprising, especially the philological point on the meaning of $\tau \mu \omega \omega \varepsilon$ ov $\sigma \alpha \varsigma$ noted at Hipp. Art. XVIIIa.385 K since Menander's Greek was not universally accepted as a model for 'good Attic' in the first few centuries AD. ${ }^{52}$ For Galen, Menander perhaps still represented a Greek usage which was widely intelligible - because of its use in mass entertainment - and thus preferable to other forms. Whatever Galen's view of Menander's Greek, the significance of this Mevóvopeıov lies in the fact that it is the title of a play 'Self-Tormentor' which is quoted, rather than anything from the text of the play itself. Given that verbal voice was a concern in Greek lexicographers ${ }^{53}$ (on whom more shortly), what we have here is a solid and eminently quotable - and perhaps thus even

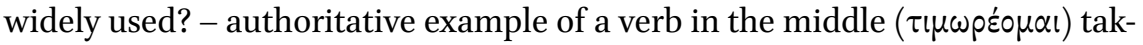
ing an accusative. The inclusion of the play name in Galen is not then indicative of a close attachment to Menader's language as such, but rather can only be interpreted as a superficial nod to his plays. This is not to say that Galen did not know - and indeed enjoy - Menander; assuming the tone of the following passage is sincere, Galen himself displays a degree of fondness for Menander in On the Natural Faculties, even if he does not speak as an advocate for his works as models of good style: ${ }^{4}$

Now such of the younger men as have dignified themselves with the names of these two authorities by taking the appellations 'Erasistrateans'

wenn man wollte, dickere Bücher füllen könnte als die Bücher des Menedotos und des Menemachos."

$\dot{\eta} \pi \alpha \lambda \alpha \dot{\alpha} \alpha \omega \mu \omega \delta \delta$ in Galen is taken in this chapter to mean 'Old Comedy' in the sense of the plays ancient Athens broadly termed, not in the modern technical sense which often differentiates strictly between Old and Middle Comedy; the fact that the labels Old, Middle and New were not used in antiquity consistently does not alter the conclusions reached in this chapter. A note on the terminology is conveniently found at Nervegna (2014) 388-89.

51 The title of a recipe given as 'an enema against dysentery from Nicostratus, which

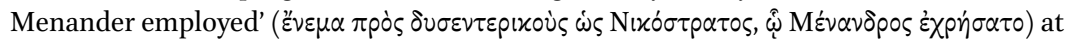
$S M T$ XIII.299 K. is unlikely (I think) to refer to the comic playwright. Karavas \& Vix 2014, $184-185$ also collect and discuss references to Menander in Galen.

On which see Tribulato (2014), who rehabilitates Menander's authoritative status for some lexicographers of the period.

53 Tribulato (2014) 208-209.

$54 \quad$ Nat.Fac. II.67 K., trans. Brock (1916). 
or 'Asclepiadeans' are like the Davi and Getae - the slaves introduced by

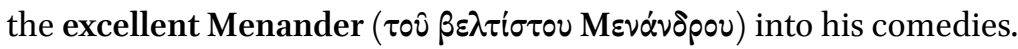

The questions of Galen's choices of what to use of Old Comedy rest partly upon which texts were extant in his lifetime, and available at Rome, Pergamum or other centres of Classical learning. ${ }^{55}$ What this section argues is that the body of material to which Galen had access when it comes to Comedy was shared with his contemporaries - as was the attitude he took to that material.

It is reasonably safe to assume that, in contrast to the more popular New Comedy, a relatively small number of complete plays of Old Comedy from fifth century BC Athens had been preserved, alongside compilatory texts with a basis in Alexandrian scholarship. ${ }^{56}$ By Galen's time at least, and most likely substantially earlier, the extant canon of Old Comedy had shrunk almost entirely to works by Cratinus, Aristophanes and Eupolis, and of these Aristophanes was pre-eminent. ${ }^{57}$ Galen himself in fact notes that texts written by well-known comic (and tragic) playwrights have been lost by his day, implying that he had knowledge of the names of playwrights, but no access to the texts of their plays. ${ }^{58}$ In Latin poets of the late Republic and first two centuries AD, this triad

55 As posed by Nutton (2009) 33-34. See Nicholls (2011) for libraries in Rome in Galen's lifetime, based on the new evidence of the Ind., and König et al. for libraries in general, esp. Zadorojnyi's contribution, pp. 389-398; Hanson (1998) 39 notes that if Galen did visit the library at Alexandria during his time in the city, he makes no mention of it.

56 Wilson (2014) gives a short introductory sketch of the afterlife of the texts of the plays of Old Comedy, and Quadlbauer (1960) the detail of comedy in literary criticism, covering some similar ground to Ruffell (2014); Le Guen (2014) considers the evidence for performance in the Hellenistic East and West, see esp. 369 on the choice of plays. It seems likely that only a few manuscripts of the plays of Old Comedy made it even to Alexandria - if a large number of plays did survive intact in Rome or in the Greek East, it seems likely their readership was very limited.

57 See Pfeiffer (1968) 160, 204-5 on the selection of the canonical poets. Rusten (2011) 81-2 collects some sources on the triad, Plato comicus sometimes being added, see e.g. Storey (2003) 40-41. On the basis of papyrus fragments, Sommerstein (2010) 410f. suggests a dramatic change around 300 вС whereby Eupolis, Cratinus and other comic dramatists stop being read. For Eupolis' reception in antiquity, see Storey (2003) chapter 1, esp. 34-40, who notes that knowledge of Eupolis exists primarily in the scholarly tradition (p. 34). Bakola (2010) 4 claims Cratinus was read until at least the second or mid third century AD, on the basis of the likely date of the papyrus hypothesis of Dionysalexandros.

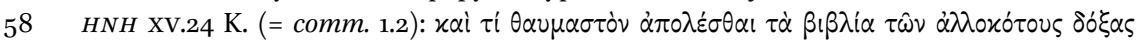

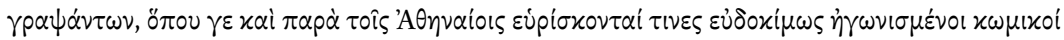

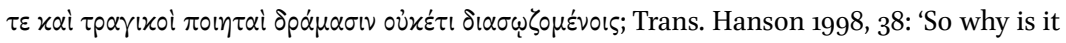


stands for the genre as a whole (for example as expressed at the beginning of Horace, Sat. 1.4.1-2), ${ }^{59}$ and the same pattern of quotation, in its paucity and preferences, appears to obtain for many Greek authors of this period, although with some obvious exceptions, such as Athenaeus. ${ }^{60}$ Even those few who may be experiencing complete plays directly are almost certainly doing so through reading, rather than performance. ${ }^{61}$

The scattered statements in the extant Galenic corpus, and Galen's catalogue of his own treatises on the subject, suggest therefore that the familiar 'big three' playwrights of Old Comedy for Galen appear to have been what broadly speaking constituted "the entire of Old Comedy" (Ind. 23b), as in many of his contemporaries. The collection of quotations and mentions of comic texts presented above shows us that Galen's preferences above all were for Aristophanes: Eupolis barely features, and Cratinus not at all. ${ }^{62}$ Galen tells us that his work on Cratinus comprised only two books, as opposed to five on Aristophanes. This suggests that Cratinus' works were already by the second century AD lesswell known, or less well-preserved, than those of Aristophanes. ${ }^{63}$ If we compare for example the scant material in Galen with the vast collection of comic fragments in Athenaeus' Deipnosophistae, the tale of a fictional symposium at which a fictionalised Galen in fact appears as a guest (he speaks about types of wine at $1.26 \mathrm{c}-27 \mathrm{~d}$, and bread at $3.115 \mathrm{c}-116 \mathrm{a}$ ) and which is most likely almost contemporaneous with the Peri alupias, Galen's range of comic material looks

surprising that the books of those who wrote down their various opinions perish, when even at Athens well-reputed comic and tragic playwrights are found with their dramas no longer surviving?'.

59 Eupolis atque Cratinus Aristophanesque poetae | atque alii, quorum comoedia prisca virorum est; see also Quintilian, Inst. 10.1.66.

6o This is a central concern in the essays collected by Marshall \& Hawkins (2016), which stands as a state-of-the-art report. On collections of quotations of Old Comedy in particular, see Sidwell (2000) 142-152 (in Athenaeus, and Lucian) and Bowie (2007) (in Dio of Prusa $f$ l. c. 70-120 AD; Aelius Aristides ? $117-181$ AD, and Maximus of Tyre $f$ l. c. 180-192 AD, and others), also including Menander. Lucian ( $f$ l. c. AD 120-180) seems to display deeper knowledge, see the more extended studies by Storey (2016), esp. 163-164 and Rosen (2016). On quotations of Menander across a range of Imperial authors, see Karavas \& Vix (2014). Nutton (2009) 24 also notes some overlap between Galen's reading and Gellius'.

61 Evidence for performance remains sketchy, although there may have been some private revivals at Rome under Hadrian, perhaps involving the the artist known as 'Attic Partridge'

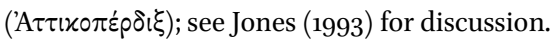

62 Notwithstanding any unnoticed quotations, given our own paucity of knowledge about Eupolis and Cratinus.

63 This echoes Ruffell's observation (2014) 303 on Latin authors that "(k)nowledge of Cratinus in particular seems less than that of his younger rivals". 
very limited indeed, and is rather on the slighter end of the scale. ${ }^{64}$ My impression is that the same can most probably also be said of the Atticist lexicographers of this period, with a focus on the canonical triad, rather than other playwrights. ${ }^{65}$ We know from literature written in Latin that, with rare exceptions and perhaps only Aulus Gellius, any engagement with Old Comedy appears to be through anecdotes in the biographical tradition or through Hellenistic scholarship, rather than first-hand knowledge. ${ }^{66}$

All this suggests that Galen is basing his work only on pre-existing compendia and lexica, and can be supported by strong echoes of quotations used by him in common with other authors. ${ }^{67}$ Eupolis' Demes, from which Galen quotes, was likely one of the best known non-Aristophanic play of Old Comedy in antiquity, ${ }^{68}$ again pointing to Galen as a more average reader of Old Comedy than we might think from his magisterial self portrayal. Storey suggests that the inclusion of the name of the speaker of the quotation of fr. * 105 in Aff. Dig. relies upon direct consultation of the play text - but concedes that this may be by Galen's source; 69 Nutton likewise notes that the long quotation from Plato comicus indicates Galen likely had a copy in his own library, but similarly there is no reason to think that these lines did not already exist as an excerpt. ${ }^{70}$ Vegetti also observes that while in $P H P$ Galen is working directly from a large number of texts of the works of philosophers and doctors, many of the quotations from poetry come via Chrysippus, i.e. an intermediary source. ${ }^{71}$

All this is not to say that Galen never read a play of Aristophanes in full, but that such reading may be more limited than it would appear at first sight. This is perhaps as a result of what was available as a full play text, but also

64 Even though Athenaeus is more important as a source for Middle Comedy, this work still preserves a great range of material from Old Comedy.

65 Searching the texts of Aelius Dionysius, Phrynichus, Pollux and Pausanias (Att.) via the $T L G$ shows 461 examples of the name Aristophanes, 128 Cratinus and 112 Eupolis (again echoing Galen's 5 books on the first of these poets, versus 2 and 3 for the other two respectively); in contrast, in these same authors there are for example only 11 examples of Philippides and 12 of Amipsias (two other comic playwrights), neither of whom are found in Galen.

66 Ruffell (2014) 302-4, in line with an interest in Old Comedy for its historical, not philological, interest; Cucchiarelli (2006) covers a slightly different range of Latin authors, and is more sympathetic as to the depth of familiarity with Aristophanes granted to some.

67 As intimated by Ruffell (2014) 304.

68 Storey (2003) 34 and 111. Eupolis, fr. * 116 is quoted by Gellius and Galen (and by Plutarch), and both also quote from Aristophanes, Merchant Ships, although different lines (Gell. $19.13 .3=$ fr. 447)

69 Storey $(2003) 37$.

$70 \quad$ Nutton $(2009) 30$.

71 Vegetti (1999) 339-340. 
perhaps because alternative sources were available - it is after all easier to recycle an existing lexical collection than it is to start from scratch. Galen is indeed clear about his working practices on this point, telling us upfront that he has produced an epitome of Didymus on Old Comedy, and is therefore using just such a pre-existing source. ${ }^{72}$ Examples of misattribution - if these are misattributions - do also support the case that he is working with anthologies or lexica, in which excerpted lines have already gone astray from their original author. We can only say for certain how far Galen was reading the complete plays of Old Comedy, and excerpting what he thought was useful, through a study of the notes and vocabulary he employs which do not feature in the lexicographical works of his near contemporaries, and through better knowledge of which plays were likely wholly extant in this period, both desiderata of future work. ${ }^{73}$ For the time being, what follows flags Galen's reuse of earlier material, albeit perhaps at the expense of downplaying his own contribution which remains to some extent unknown. It should be noted that this is not a negative judgement of Galen's work, nor anything of which he himself was ashamed. Wilkins' words ring just as true for Galen's lexicography as of his medical works: 'Compiling is not a term of abuse (as it is often applied to Athenaeus), in the mind of Galen at least, since he, the cataloguer with utility in mind, clearly sees it as vital for medical practice. ${ }^{74}$

Despite the scorn which Galen often pours on those Atticisers who are concerned with linguistic 'quibbling', it is striking that there is a small but significant overlap between Galen's own works and the surviving contemporary Atticising lexica, ${ }^{75}$ particularly in the choice of words discussed. ${ }^{76}$ This includes a number of words which are very rarely found in the extant corpus

72 As Galen similarly relied on digests of some medical and other materials, used at secondhand, see e.g. Roselli (1999) on medical digests and Hanson (1998) 35-7 for collected bibliography on earlier commentaries and lexica relating to Hippocrates.

Manetti (2009) 161-1 indeed argues that the lack lexicographical analogue to the fragment of Aristophanes quoted at Hipp. Fract. indicates Galen's own 'careful studies' of the language of comic poets.

74 Wilkins (2007) 85.

75 Strobel (2009) is a convenient introduction to some of the major Atticist lexica.

76 Both this scorn for Atticists, and engagement with their material, can be seen for example in Alim. Fac. 2.29.3 (= VI.612 K.; trans. Powell 2003, 94 adapted): "Some of those who call themselves Atticisers, who have practiced no skill of value for life, think it right to refer to this fruit in the feminine amygdale ( $\dot{\alpha} \mu \nu \gamma \delta \dot{\alpha} \lambda \eta)$ 'almond', but others of them in the neuter amygdalon ( $\dot{\alpha} \mu \dot{\gamma} \gamma \delta \alpha \lambda \circ v)$, not realizing about this very matter that they take so seriously, that the Athenians wrote both names". This word and its gender also features in Moeris (Lexicon Atticum $\alpha 15)$ and Athenaeus 2.52f (= 2.39-40 Kaibel); other such examples of comments on the gender of Classical words which co-occur across different lexica from this period, and in Galen, are collected in Appendix A of Coker (2010). 
of Greek texts up to and including Galen, but yet feature frequently - sometimes more frequently - in the lexicographical tradition. To give just two ex-

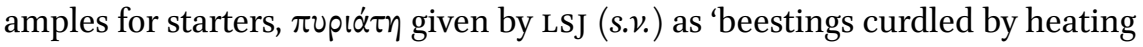
over embers' 77 and its synonym $\pi$ vi $\varepsilon \varphi \theta$ ov, are found only a handful of times in texts from Classical antiquity (Eubulus $f r .74$ (K-A) ('O $\beta \beta$ ía), Aristophanes,

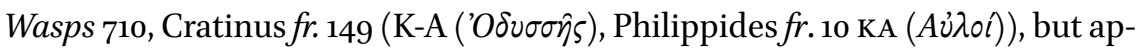
pear in Aelius Dionysius $\pi 77$ (Erbse), ${ }^{78}$ Pausanias $\pi 43$ (Erbse), ${ }^{79}$ Pollux 1.248 (Bethe), ${ }^{80}$ Galen, Alim. Fac. vi.694 K., ${ }^{81}$ and elsewhere in the later lexicographical tradition, all in relatively similar formulations. This strongly suggests that Galen is reading and replying to one or more live lexicographical traditions (represented here by Aelius Dionysius et al.) which draw at least indirectly on Hellenistic and Alexandrian scholarship. Put differently - and more pejoratively - we might say that Galen has a close connection with contemporary 'sophistical' work.

This is supported further by the mention of a work by Didymus at Ind. 24a. Assuming Galen's Didymus is the famous Alexandrian scholar Didymus Chalcenterus ("bronze-guts") of the first century вс, ${ }^{82}$ then the work from which Galen composed his own epitome is one of the 3,500-4,000 works he allegedly composed, or a version of one of them. Writing almost at the end of the great Alexandrian tradition of scholarship, Chalcenterus' works are generally characterised as derivative, based in turn mostly on the works of earlier lexicographers and commentators such as Aristophanes of Byzantium. ${ }^{83}$ Pfeiffer

77 Meaning a type of cheese made from cow colostrum; such a cheese is made in Tamil Nadu and Ukraine.

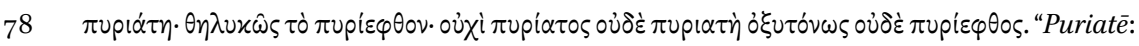
Feminine, and means puriephthon. There is no word puriatos or puriate (accented on the final syllable), nor puriephthos."

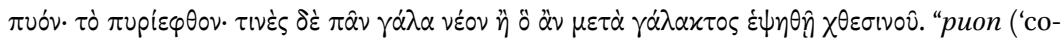
lostrum'): (means) puriephthon. Some people use this to mean any milk, either fresh or whatever is boiled with yesterday's milk."

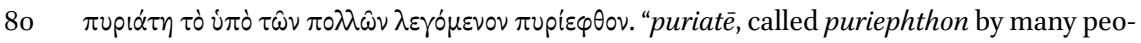
ple." $\pi$ upid́ $\tau \eta$ is also found at Pollux 6.54, where Philippides is quoted.

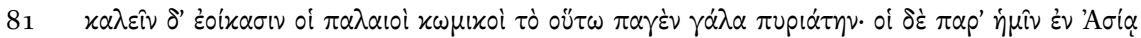

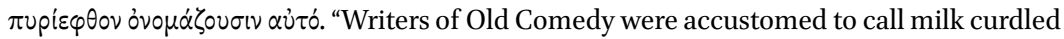
in this way puriatē; we in Asia name the same thing puriephthon."

$82 \quad$ BJP ad Ind. 24a (= p. 81) identifies this Didymus as Chalcenterus, but there are other can-

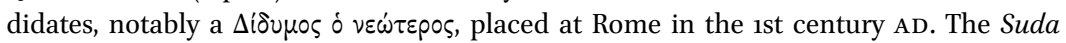
lists three Didymi as grammarians $(\delta 872-4)$, who may not all be discrete individuals. See Dickey (2007) 7, n. 18 as an entry into the debate.

83 West (1970) has a rather poor view of the quality of Didymus' historical and philological scholarship; Pfeiffer (1968) 279 is altogether more positive, seeing Didymus' vast output as only possible (he was only "enabled to become the most efficient servant of an ancient 
notes that after Homer, this scholar's prime focus was Attic comedy: he collected a vast amount of information on "literary, historical, biographical and prosopographical" matters, and we know he compiled a work on comic words

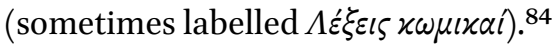

If Galen is indeed using a text circulating under the name of Didymus' Comic Words, it is just possible that there are traces of this work at the end of the passage from the $\pi \varepsilon p i \dot{\alpha} \lambda v \pi i$ s with which this chapter started (26-7). A convincing emendation by Polemis (above p. 63, n. 2) conjectures two words given by Galen as examples of the sorts of unclear vocabulary items which his treatise helped to explicate: $\alpha \beta v \delta o x o ́ \mu \eta \varsigma$ and $\alpha \beta v \rho \tau \dot{\alpha} x \eta$. The first of these appears a handful of times in the lexicographical tradition - and only in this tradition - as a nickname for a sycophant ${ }^{85}$ and the second, only marginally more common, is a type of sauce (LSJ s.v. "sour sauce of leeks, cress, and pomegranate-seeds"). ${ }^{86}$ Nutton has already suggested that these two words, both beginning with $\alpha \beta-$, may well have stood at the beginning of Galen's own treatise on Old Comedy - if it was arranged alphabetically. ${ }^{87}$ Some evidence however for both words as coming directly from a pre-existing lexicographical tradition is also found in Pausanias' lexicon, (mid/late 2nd century AD), which in its sur-

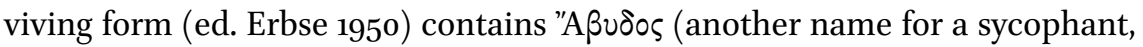

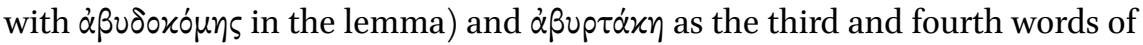
Alpha. ${ }^{88}$ It seems unlikely that such organisational similarities would appear across different texts if both Galen and Pausanias were independently alphabetising a non-alphabetical source, or were using no source text at all.

intellectual community", in Pfeiffer's own words) because of the peace brought about by Augustus. Manetti (2009) 165 flags the role played by work by Aristophanes of Byzantium in some of Galen's lexicographical material: Didmyus may thus be the intermediary source.

84 Pfeiffer (1968) 276. Scant fragments of a work given the title $\Lambda \dot{\varepsilon} \xi \iota \varsigma \omega \mu \iota x \dot{\eta}$ are collected at

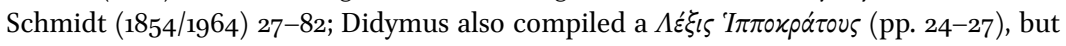
whether this was available to Galen must remain speculation.

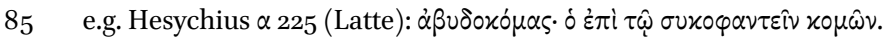

86 Found for example at Pherecrates, fr. 185 K-A, Theopompus fr. 18 ( $\Theta \eta \sigma \varepsilon u ́ s)$ K-A, Antiphanes

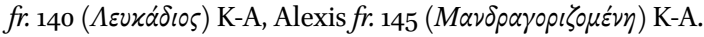

$87 \quad$ Nutton (2013) 86 n. 57 .

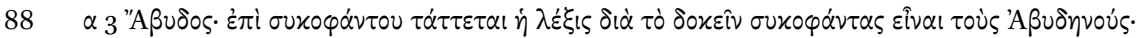

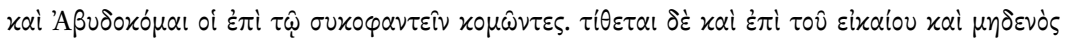

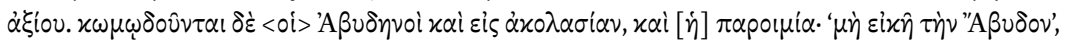

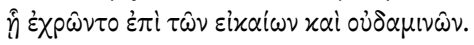

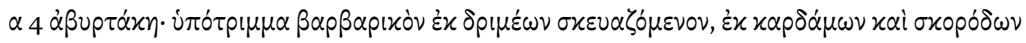

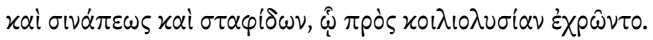

For the use of the town name Abydos as an abusive epithet, see Kajava (2007) 25-28. 
It is not unreasonable to assume that Galen maintained this alphabetical order in his own work, which is why these two words appear as they do in the Peri alupias, standing as the first two of his now-lost epitome, and recalled from memory. Galen is often in favour of alphabetisation (order $x \alpha \tau \dot{\alpha} \sigma \tau 0$ (x $\varepsilon \hat{\imath} 0 \nu$ ), although he also used other arrangements of material. ${ }^{89}$ Alphabetical order is used for example in some of the books of $S M T$ (e.g. 6, 7 and 8, all on plants), where Galen explicitly tells his reader he is imitating the order of an earlier work by Pamphilus, On Plants (6, proem $=$ XI.793-4 K.); $;{ }^{90}$ the Glossary of Hippocratic Terms (Gloss.) is in addition fully alphabetical, in contrast to other contemporary lexica which are only broadly so. ${ }^{91}$ It seems likely too that Galen's forty-eight book work on Attic prose was also alphabetical: just before the passage from Lib. Prop. quoted earlier in this chapter on p. 65 Galen tells us about another $\pi p \alpha \gamma \mu \alpha \tau \varepsilon i \alpha$ of his, identified with this work on prose,

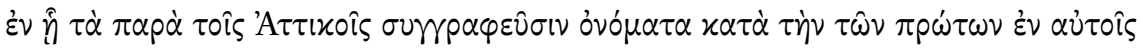
$\gamma \rho \alpha \mu \mu \dot{\alpha} \tau \omega \nu \ddot{\eta} \theta p o l \sigma \tau \alpha l \tau \dot{\alpha} \xi\left(\nu .{ }^{92}\right.$

There are however traces of an alternative, thematic pattern of arrangement in this passage from the Ind. If lexical collections such as that by Didymus, or versions of it, represent one body of knowledge from which Galen was drawing (in common with Atticist lexicographers, Pollux, Lucian etc.) there may be an additional body of work also evident. At Ind. 27 (repeated below from the beginning of this chapter), Galen gives what looks like a list of contents, although it is not immediately clear whether this list refers to the mentioned work by Didymus, or to Galen's own epitome:

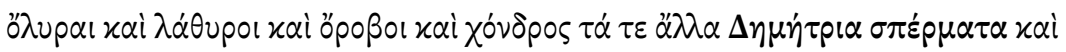

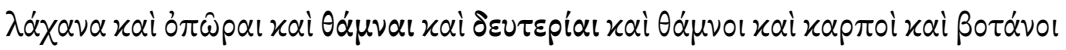

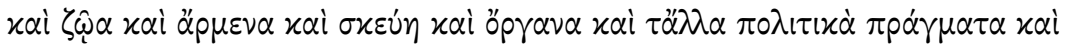
óvó $\mu \alpha \tau \alpha \pi \dot{v} v \tau \alpha$.

89 On the various methods of presentation of material used by Galen, see Flemming (2007) $247-58$, and passim, and the comments below.

9o Wilkins (2007) 81: 'Galen appears to find Pamphilus to be a bad botanist, but a good lexi-

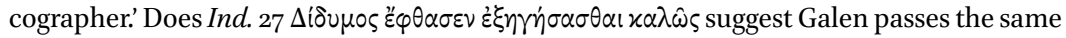

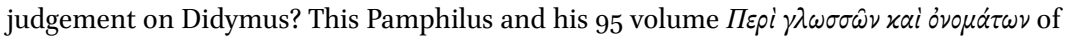
the ist century AD is sometimes seen as an intermediary between Didymus' work and grammarians of the second century AD.

91 Dickey (2007) 45. Purely alphabetical arrangements of material was not the rule, although there were for example earlier texts of medical interest arranged $x \alpha \tau \dot{\alpha} \sigma \tau \circ \chi x \varepsilon \hat{\imath} \mathrm{v}$, see Flemming (2007) 254; compare Pollux' Onomasticon as an example of the encyclopedic or thesaurus format, as Tosi (2007) $3-5$. On alphabetisation in antiquity, see Daly (1967) 9-69.

Ord. Lib. Prop 5.1-2 (= XIX.6o K.). 
emmer, chick peas, vetch, groats and the other cereals, vegetables and late-summer fruits, wines made from the marc of grapes, with or without the addition of water, bushes, fruits, plants, animals, instruments, equipment, tools, and everything else in daily life, and their names.

Rosen sees this list as an allusion to catalogues of foodstuffs in Old Comedy, ${ }^{93}$ but two strong echoes are found much closer to lexicographical home. The list - and in particular the order in which items appear - bears more than a passing resemblance to a passage in Pollux 1.247-8 (the text is untranslated because of the large number of synonyms):

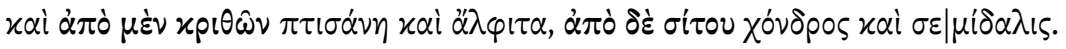

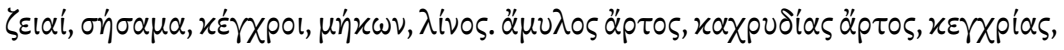

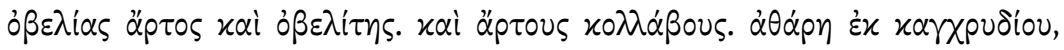

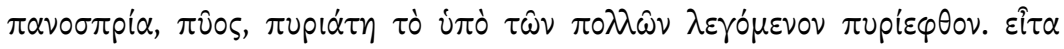

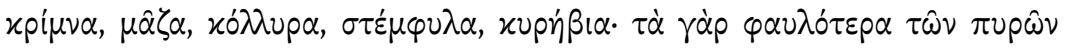

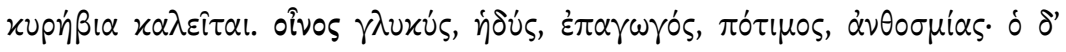

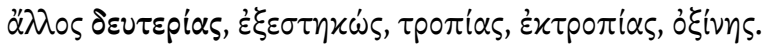

First in Pollux are listed grains and cereals (including $\chi 0$ ó $\delta$ pos, the word used by the 'respected doctor' whose opinion Galen debunks in Ind. 26) - equivalent to the $\Delta \eta \mu \eta \dot{\tau} \tau 1 \alpha \sigma \pi \varepsilon \dot{p} \mu \alpha \tau \alpha$ of Ind. 27 - and then wines of various kinds, including

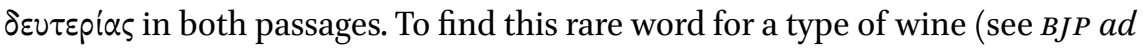
Ind. 27, = pp. 90-2) reinforces the idea that the similarities between these two passages are more than chance. $\pi$ viór $\tau$ - given above as an example of the strength of grammatical tradition - also appears here. The second passage for comparison is from Galen's Med. Nom. ${ }^{94}$

Nun haben jene Leute, wenn sie dies behaupten, doch nicht nur keine Kenntnis von der Natur und dem Wesen des Blutes oder vom Wesen der heißen Schwellung, welche auf griechisch $\varphi \lambda \varepsilon \gamma \mu$ ovn' heißt, oder vom Wesen der Augenentzündung (Ophthalmie), sondern es entgeht ihnen die Kenntnis vom Wesen des Weizens, von dem Wesen der Gerste, dem Wesen der Kichererbse, dem Wesen der Pferdebohne, dem Wesen des Öls und dem Wesen des Weines: außerdem kennen sie ja auch nicht richtig das Wesen von irgendwelchen Pflanzen oder Tieren, wie sie (selbst) ihr eigenes Wesen nicht kennen.

93 Rosen (2014) 169.

94 Meyerhof \& Schacht (1931) $27=99 \mathrm{v}$. 
Now those people, when they say this, are not only unaware of the nature and the essence of blood or of the nature of the hot swelling which is called $\varphi \lambda \varepsilon \gamma \mu$ ov $\eta$ in Greek, or of the nature of inflammation of the eye (ophthalmia), but they are also lacking in knowledge of the nature of wheat, barley, chickpea, horsebean, oil and wine: in addition they do not really know about the nature of any plants or animals, just as they do not even know their own nature.

Even though we are several stages here removed from Galen's Greek (through the German translation of the Arabic text, which is in turn a translation of the Greek), again we have a list (corresponding to the emboldened words) com-

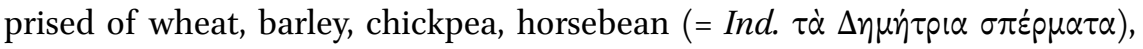

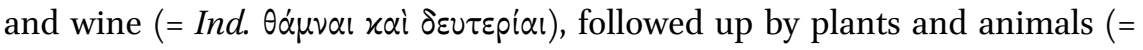

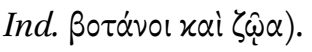

This arrangement of substances - and in the order grains, plants and animals is also used by Galen in Alim. Fac., and indeed specifically outlined there as a ranking of the relative values of foodstuffs. ${ }^{95}$ There were various ways of organising edible substances and their subsets in dietetic treatises in antiquity, often sophisticated and complex, but some sets of similar principles appear to have operated. ${ }^{96}$ More work needs to be done on outlining such organisational principles before Galen, but it seems likely that the lists we find here are in some way a reflection of an earlier tradition.

There are also echoes of the vocabulary in Alim. Fac. of this list in Ind: the $\Delta \eta \mu \eta \dot{\tau} p 1 \alpha \sigma \pi \varepsilon \dot{p} \mu \alpha \tau \alpha$ again appear (Alim. Fac. 2.1 = VI.554-5 K., and elsewhere in Galen), as does $\delta \varepsilon v \tau \varepsilon p i \alpha \varsigma$ (Alim. Fac. 2.9 = VI.58o K.) to give just two examples. The only places that this latter word appears in Galen are here in the Alim. Fac., and in the Ind.. It may be significant that in the first of these treatises Galen

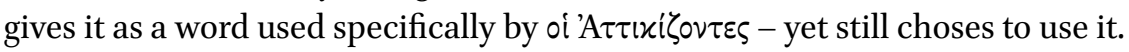

There are a number of possible explanations of these two sets of correspondences, none of which however can be proved conclusively. It is on the face of it impossible to posit a single source text for Galen's treatise on Old Comedy which is both alphabetical and thematic: are there then rather multiple texts from which Galen is compiling his new work, one alphabetical collection of words also used by some Atticist lexica, and one thematic used by Galen and

95 Book 1 is the grains, with legumes and pulses; Book 2 vegetables and fruits and Book 3 animal products. See Wilkins' foreword (p. ix) to Powell's translation (2003); Galen outlines and justifies his order at Alim. Fac. 2.1 (= VI.554-5 K.).

96 For plants, for example, either based around appearance, or effect on the body. Hardy \& Totelin (2016) 63-92 sketch some of the wider taxonomic landscape, with pp. $75^{-88}$ on various ancient systems of classification. 
Pollux? Or, does the correspondence with Pollux indicate only a close relationship between these two authors, and Pollux is influenced by Galen, rather than any prior text which both share? ${ }^{97}$ On balance - and however Pollux fits into this picture - it seems more likely on the basis of the limited evidence presented here that Galen's own text on Old Comedy was arranged alphabetically, and that the list of topics given at Ind. 27 represented his own ideas about arrangement, perhaps a list which automatically came to mind at the very mention of foodstuffs. If a written text with thematic arrangement does however lie behind the list - and even goes back to some work of Didymus, if the list at Ind.

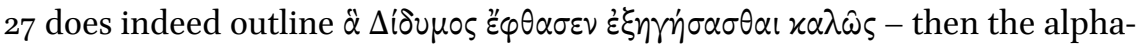
betical coincidences highlighted above must however still be accounted for.

This chapter has sought to think in more concrete terms about the shape and contents of a lost work of Galen described in the $\pi \varepsilon p i \dot{\alpha} \lambda \nu \pi i a s$, and in doing so to place Galen within the literary and lexicographical culture of the Roman empire of the late second century AD.

In structural terms, Galen's epitome of Didymus on Comedy may have been alphabetical (starting with abudokomas and $a b u r t a k e \overline{)}$ ), but there are also striking indications of the presence of a thematic organisational principle: it remains unclear however whether Galen in alluding to these two systems is referring to his own collection of words, or Didymus'. As to contents, from looking at Galen's use of Old Comedy elsewhere in his works his preferences can be seen to be very similar to those educated men who either passed judgement on, or sought to emulate or to play with, Atticist usage. In common with some other works of the period, Galen's lost treatise similarly drew on Didymus and a longer scholastic tradition on Attic Old Comedy, so we might speculatively ponder that a set of words similar to those preserved in other ancient works on comedy was also at the core of Galen's work. While this perhaps underplays the breadth of Galen's reading, there are nevertheless strong indications that he is engaging closely with lexical collections circulating at Rome and other centres of learning at the period - and even their authors. Correspondences with

97 Zecchini (2007) 22-4 outlines Pollux's use of a wide range of non-canonical treatises. More work is certainly needed on the relationships between the works of Galen and Pollux, and as noted in the review of a recent work on Pollux (Rance 2008), also on the setting of Pollux's lexicon in 'the vast output of grammarians and lexicographers of the Antonine period' in general. 
Lucian are perhaps most curious: note also that Galen's very rare $\dot{\beta} \beta \nu \tau \tau^{\alpha} x \eta \eta$ used in Lucian's satirical Lexiphanes 6 among a list of foodstuffs (as well as at Pollux 6.56), a work which rejoices in particular in its handling of the vocabulary of Old Comedy - and indeed some have suggested that the doctor character in this work is a mockery of Galen himself. ${ }^{98}$ We can thus align Galen very closely with other members of the literary élite of the second century AD who are also looking back to comic exemplars of the fifth century вс, and see the extent to which he was likewise deeply entrenched in Atticising cultures.

While we see Galen using these already seven-hundred-year-old texts to make linguistic points, they are sometimes deployed simply to demonstrate his education. This verges on the use of words as ornaments - the very thing Galen argues should be guarded against. It is not surprising however that Galen, imbued with the paideia of the period, should draw on his 'internalisation' of classical literature for its rhetorical power, ${ }^{99}$ but the manner in which he does so places him somewhat closer to those he criticises than he has previously been seen to be. In the judgement of history it is a fine - and often subjective - line which separates a positively-viewed Galen, imbued with wide and earnestlearning, aptly demonstrated to good purpose, from the schoolish ${ }^{100}$ or reductive Galen who slavishly reproduces as fripperies those examples acquired and collected in common with the rest of the educated elite. Galen himself certainly sought to distance himself from elements of the latter and those he would label as 'sophists', composing a strongly militaristic polemic against them at the end of the first book of On Medical Names. ${ }^{101}$ In this fight over good Greek however, Galen's weapons are remarkably similar to those used by his sophistical foes.

98 See the bibliography at Storey (2016) 176, n. 32, who argues for a different identification. Perhaps it is significant that the words put into the fictional Galen's mouth by Athenaeus are on wine $(1.26 \mathrm{c}-27 \mathrm{~d})$ and bread, grains and their nutritiousness $(3.115 \mathrm{c}-116 \mathrm{a})$ - was Galen known to his contemporaries to be particularly vociferous on such topics? See Wilkins (2007) 78-9 on these two passages and the 'reality' of Athenaeus' Galen passim.

$99 \operatorname{Rosen}(2013) 188$.

100 As Karavas \& Vix 2014, 185.

101 Meyerhof-Schacht (1931) $37=$ 107v: "Ich habe dieses mein ganzes Buch um jener Sophisten willen verfaßt; es ist ein Buch, das, wenn es in der Welt keine Streitfrage über diese Angelegenheit gäbe, ein nutzloses Gefasel und eine Sinnlosigkeit wäre; so wie der Mensch genötigt ist, die Waffe zu ergreifen und zu seiner Ausrüstung zu machen, nur wegen der schlechten Menschen - nur wenn in der Welt nicht ein einziger von den Menschen schlecht wäre, wäre es überflüssig, sie zu ergreifen und bereitzuhalten -, so ist meine Rede in diesem meinem Buche gleichsam eine Waffe und Ausrüstung zum Kampfe gegen die Sophisten." 


\section{Acknowledgements}

My thanks are due to the many people who have commented on this paper, both in Warwick and since, in particular to Vivian Nutton for supplying me with a copy of Polemis 2011, Laurence Totelin for kindly sharing with me then forthcoming work, and Nicky Bigwood for help with the German. This paper is an offshoot from a Leverhulme Trust Early Career Fellowship (2013-2016) hosted by the Department of Classics and Ancient History at the University of Manchester; the support of both the Trust and the Department is here gratefully acknowledged.

\section{References}

Bakola, E. Cratinus and the Art of Comedy. Oxford: oup, 2010.

Barnes, J. 'Logique et pharmacologie: à propos de quelques remarques d'ordre linguistique dans le De simplicium medicamentorum temperamentis ac facultatibus de Galien'. In Galen on Pharmacology, ed. A. Debru, 3-33. Leiden: Brill, 1997.

Bowie, E. 'The Ups and Downs of Aristophanic Travel'. In Aristophanes in Performance $421 B C-A D 2007$, ed. E. Hall \& A. Wrigley, 32-51. London: Legenda, 2007.

Coker, A. Aspects of Grammatical Gender in Ancient Greek. Manchester: PhD. diss. University of Manchester, 2010.

Cucchiarelli, A. 'La commedia greca antica a Roma'. Atene e Roma 51.4, (2006): 157-77.

Daly, L. A. Contributions to a History of Alphabetization in Antiquity and the Middle Ages. Collection Latomus Vol. xc. Bruxelles: Latomus, 1967.

Deichgräber, K. (1957) 'Parabasenverse aus Thesmophoriazusae II des Aristophanes bei Galen', Sitzungsberichte der Akademie der Wissenschaften zu Berlin, Klasse für Sprache, Literatur und Kunst 1956.2. Berlin: Akademie Verlag, 1957.

De Lacy, P. 'Galen and the Greek Poets'. GRBs 7.3 (1966): 259-66.

Dickey, E. Ancient Greek Scholarship. Oxford: OUP, 2007.

Erbse, H. Untersuchungen zu den atticistischen lexica. Berlin: Akademie Verlag, 1950.

Flemming, R. 'Galen's imperial order of knowledge'. In Ordering Knowledge in the Roman Empire, ed. J. König \& T. Whitmarsh, 241-277. Cambridge: CUP, 2007.

Hankinson, J. 'Usage and abusage: Galen on language'. In Language. Companions to Ancient Thought 3, ed. S. Everson, 166-87. Cambridge: Cambridge University Press, 1994.

Hanson, A. E. 'Galen: Author and Critic'. In Editing Texts/Texte edieren, Aporemata Band 2, ed. G. W. Most, 22-53. Göttingen: Vandenhoeck \& Ruprecht, 1998.

Hardy, G. \& L. Totelin. Ancient Botany. London: Routledge, 2016. 
Johnson, W. A. Bookrolls and Scribes in Oxyrhynchus. Toronto: University of Toronto Press, 2004.

Jones, C. P. 'Greek Drama in the Roman Empire'. In Theater and Society in the Classical World, ed. R. Scodel, 39-52. Ann Arbor: The University of Michigan Press, 1993.

Kajava, M. 'Cities and Courtesans'. Arctos 41 (2007): 21-29.

Karavas, O. \& J.-L. Vix. 'On the Reception of Menander in the Imperial Period'. In Menander in Contexts, ed. A. H. Sommerstein, 183-198. London: Routledge, 2014.

Kim, L. 'The Literary Heritage as Language: Atticism and the Second Sophistic'. In $A$ Companion to the Ancient Greek Language, ed. E. J. Bakker, 468-82. Oxford: Wiley Blackwell, 2010.

Kollesch, J. 'Galen und die Zweite Sophistik'. In Galen: Problems and Prospects, ed. V. Nutton, 1-11. London: The Wellcome Institute for the History of Medicine, 1981.

König, J., K. Oikonomopoulou \& G. Woolf. Ancient Libraries. Cambridge: CUP, 2013.

Le Guen, B. 'The Diffusion of Comedy from the Age of Alexander to the Beginning of the Roman Empire'. In The Oxford Handbook of Greek and Roman Comedy, ed. M. Fontaine \& A. C. Scafuro, 359-77. Oxford: OUP, 2014.

Manetti, D. 'Galen and Hippocratic medicine: language and practice'. In Galen and the World of Knowledge, ed. C. Gill, T. Whitmarsh \& J. Wilkins, 157-74. Cambridge: CUP, 2009.

Manetti, D. \& A. Roselli. 'Galeno commentatore di Ippocrate'. ANRW II 37.2, (1994): 1529-635.

Marshall, C. W. \& T. Hawkins. Athenian Comedy in the Roman Empire. London: Bloomsbury, 2016.

Meyerhof, M. \& J. Schacht 'Galen, Über die medizinischen Namen, arabisch und deutsch', Abhandlungen der preussischen Akademie der Wissenschaften. Berlin: Verlag der Akademie der Wissenschaften, 1931.

Morison, B. 'Language'. In The Cambridge Companion to Galen, ed. R. J. Hankinson, 116-156. Cambridge: CUP, 2008.

Nervegna, S. 'Contexts of reception in antiquity'. In The Cambridge Companion to Greek Comedy, ed. M. Revermann, 387-403. Cambridge: CuP, 2014.

Nicholls, M. C. 'Galen and Libraries in the Peri Alupias'. JRS 101 (2011): 123-42.

Nutton, V. 'Galen's Library'. In Galen and the World of Knowledge, ed. C. Gill, T. Whitmarsh \& J. Wilkins, 19-34. Cambridge: CUP, 2009.

Nutton, V. 'Avoiding Distress'. In Galen. Psychological Writings, ed. P. N. Singer, 45-106. Cambridge: CUP, 2013.

Pfeiffer, R. History of Classical Scholarship. Vol. 1. Oxford: Clarendon Press, 1968.

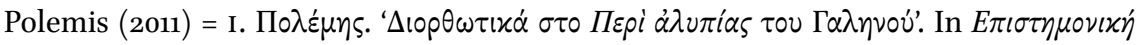

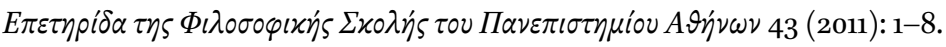

Powell, O. Galen on the Powers of Foodstuffs. Cambridge: CUP, 2003. 
Quadlbauer, F. 'Die Dichter der grieschischen Komoödie im literatischen Urteil der Antike'. Wiener Studien 73 (1960): 40-82.

Rance, P. Review of L'onomasticon Giulio Polluce. Tra lessicografia e antiquaria, ed. C. Bearzot, F. Landucci \& G. Zecchini, 3-16. Milano: Vita e Pensiero, 2007. BMCR 2008.11.28.

Roselli, A. 'Notes on the doxai of doctors in Galen's commentaries on Hippocrates'. In Ancient Histories of Medicine. Essays in Medical Doxography and Historiography in Classical Antiquity, SAM 20, ed. P. van der Eijk, 359-81. Leiden: Brill, 1999.

Rosen, R. M. 'Galen on Poetic Testimony'. In Writing Science. Medical and Mathematical Authorship in Ancient Greece, ed. M. Asper, 177-189. Berlin: De Gruyter, 2013.

Rosen, R. M. 'Philology and the Rhetoric of Catastrophe in Galen's De indolentia'. In Galen's De Indolentia. Essays on a Newly Discovered Letter, ed. C. K. Rothschild \& T. W. Thompson, 167-172. Tübingen: Mohr Siebeck, 2014.

Rosen, R. M. 'Lucian's Aristophanes: On Understanding Old Comedy in the Roman Imperial Period.' In Athenian Comedy in the Roman Empire, ed. C. W. Marshall \& T. Hawkins, 141-162. London: Bloomsbury, 2016.

Ruffell, I. 'Old Comedy at Rome: Rhetorical Model and Satirical Problem.' In Ancient Comedy and Reception. Essays in Honor ofJeffrey Henderson, ed. S. D. Olson, 275-308. Berlin: De Gruyter, 2014.

Rusten, J. (ed.) The Birth of Comedy: texts, documents, and art from Athenian competitions, 486-28o. Baltimore: Johns Hopkins University Press, 2011.

Schmidt, M. Didymi Chalcenteri grammatici Alexandrini fragmenta quae supersunt omnia. Leipzig/Amsterdam, 1854/1964.

Schmitz, T. Bildung und Macht. Zur sozialen und politischen Funktion der Zweiten Sophistik in der griechischen Welt der Kaiserzeit. Munich, 1997.

Sidwell, K. 'Athenaeus, Lucian and Fifth-Century Comedy.' In Athenaeus and his World. Reading Greek Culture in the Roman Empire, ed. D. Braund \& J. Wilkins, 136-152. Exeter: University of Exeter Press, 2000.

Skoda, F. 'Galien Lexicologue'. In Dieux, héros et médecins grecs, ed. M. Woronoff, S. Follet \& J. Jouanna, 177-95. Paris: Presses Universitaires Franc-Comtoises, 2001.

Sluiter, I. 'The embarrassment of imperfection: Galen's assessment of Hippocrates' linguistic merits.' In Ancient Medicine in its Socio-Cultural Context, Volume 2, ed. P. van der Eijk, H. F. J. Horstmanshoff \& P. H. Schrijvers, 519-535. Amsterdam: Rodopi, 1995. Sommerstein, A. H. 'The History of the Text of Aristophanes'. In Brill's Companion to the Study of Greek Comedy, ed. G. W. Dobrov, 399-422. Leiden: Brill, 2010.

Staden, H. von 'Science as text, science as history: Galen on metaphor'. In Ancient Medicine in its Socio-Cultural Context, Volume 2, ed. P. van der Eijk, H. F. J. Horstmanshoff \& P. H. Schrijvers, 499-518. Amsterdam: Rodopi, 1995.

Staden, H. von 'Gattungen und Gedächtnis: Galen über Wahrheit und Lehrdichtung'. In Gattungen wissenschaftlicher Literatur in der Antike, ed. W. Kullman, J. Althoff \& M. Asper, 65-94, Scripta Oralia 95. Tübingen: G. Narr, 1998. 
Storey, I. C. Eupolis. Poet of Old Comedy. Oxford: OUP, 2003.

Storey, I. C. 'Exposing Frauds: Lucian and Comedy'. In Athenian Comedy in the Roman Empire, ed. C. W. Marshall \& T. Hawkins, 163-180. London: Bloomsbury, 2016.

Strobel, C. 'The Lexica of the Second Sophistic: Safeguarding Atticism.' In Standard Languages \& Language Standards: Greek, Past and Present, ed. A. Georgakopoulou \& M. Silk. Farnham: Ashgate, 2009.

Swain, S. Hellenism and Empire. Language, Classicism \& Power in the Greek World AD 50-25o. Oxford: OUP, 1996.

Tosi, R. 'Polluce: struttura onomastica e tradizione lessicografia'. In L'onomasticon Giulio Polluce. Tra lessicografia e antiquaria, ed. C. Bearzot, F. Landucci \& G. Zecchini, 3-16. Milano: Vita e Pensiero, 2007.

Tribulato, O. “Not even Menander would uses this word!" Perceptions of Menander's Language in Greek Lexicography.' In Menander in Contexts, ed. A. H. Sommerstein, 199-214. London: Routledge, 2014.

Vegetti, M. 'Tradition and truth. Forms of philosophical-scientific historiography in Galen's De placitis'. In Ancient Histories of Medicine. Essays in Medical Doxography and Historiography in Classical Antiquity, SAM 20, ed. P. van der Eijk, 333-57. Leiden: Brill, 1999.

West, S. 'Chalcentric Negligence', Classical Quarterly, 20.2, (1970): 288-96.

Wilkins, J. 'Galen and Athenaeus in the Hellenistic Library'. In Ordering Knowledge in the Roman Empire, ed. J. König \& T. Whitmarsh, 69-87 Cambridge: CUP, 2007.

Wilson, N. 'The transmission of comic texts'. In The Cambridge Companion to Greek Comedy, ed. M. Revermann, 424-32. Cambridge: CUP, 2014.

Zadorojnyi, A. V. 'Libraries and paideia in the Second Sophistic'. In Ancient Libraries, ed. J. König, K. Oikonomopoulou \& G. Woolf, 377-400. Cambridge: CUP, 2013.

Zecchini, G. 'Polluce e la politica culturale di Commodo'. In L'onomasticon Giulio Polluce. Tra lessicografia e antiquaria, ed. C. Bearzot, F. Landucci \& G. Zecchini, 17-28. Milano: Vita e Pensiero, 2007.

\section{Texts and Editions}

Galen. The Order of My Own Books (Ord. Lib. Prop.), On My Own Books (Lib. Prop.). Ed. V. Boudon-Millot. Paris: Les Belles Lettres, 2007. English trans. P. Singer, Galen: Selected Works. Oxford: OUP, 1997.

Galen. On Avoiding Distress (Ind.). Ed. V. Boudon-Millot, J. Jouanna \& A. Pietrobelli. Paris, Les Belles Lettres, 2010. (= BJP) English trans. V. Nutton, v. 'Avoiding Distress'. In Galen. Psychological Writings, ed. P. N. Singer, 45-106. Cambridge: CUP, 2013. Galen. On the Natural Faculties (Nat. Fac.). Trans. A. J. Brock. London: Heinemann, 1916. Galen. OnMedicalNames (Med. Nom.) Arabic text and German translation M. Meyerhof \& J. Schacht. Berlin: Verlag der Akademie der Wissenschaften, 1931.

Galen. On the Properties of Foodstuffs. Trans. O. Powell. Cambridge: CUP, 2003. 


\section{Abbreviations}

CMG V 4.1.2 = De Lacy, P. Galeni De placitis Hippocratis et Platonis, CMG V 4.1.2. Berlin, 1978-1984. (= PHP)

CMG V 4.2 = Helmreich, G. Galeni De alimentorum facultatibus libri III, De bonis malisque sucis, cMG V 4.2. Berlin, 1923. (= Alim. Fac.)

CMG V 9.1 = Helmreich, G. Galeni in Hippocratis De victu acutorum Commentaria IV, $C M G$ V 9.1. Berlin, 1914. (= HVA)

CMG V 10.2.2 = Wenkebach, E. \& F. Pfaff Galeni in Hippocratis Sextum Librum Epidemiarum commentaria I-VI, CMG V 10.2.2. Berlin, 1956. (= Hipp. Epid. on book 6) PCG = Poetae comici Graeci, 8 volumes, ed. R. Kassel \& C. Austin. Berlin: Walter de Gruyter, 1983-2001 